\title{
Family versus School Effect on Individual Religiosity: Evidence from Pakistan
}

\begin{abstract}
This paper presents an empirical analysis of the impact of school type on students' levels of religiosity. We use a new dataset on female students of registered madrasas (Islamic schools) and secular schools from urban parts of Pakistan. On most counts of religious behavior the students from the two groups record broadly similar results. However, our probit analysis shows that when we control for students' socio-economic profile and attitudes, on few counts of religiosity madrasa effect does emerge but it disappears as soon as we control for parental level of education. Our findings support the hypothesis that parental education, especially mother's education, is key to modernising religious and cultural norms in conservative societies.
\end{abstract}

Key words - madrasa and secular schools, mother's education, religious belief, practical faith, Pakistan, South Asia

\section{INTRODUCTION}

Since September 11, in international security debates madrasas (Islamic schools) have been associated with Islamic militancy. This concern has been particularly strong about madrasas in Pakistan as many Taliban leaders were schooled in madrasas on the borderland of Pakistan and Afghanistan (Haqqani 2005; Rashid 2010; Ahmad 2015). Consequently, many development agencies have attempted to invest in madrasa modernisation programmes ${ }^{1}$. Survey based studies aimed at comparing students from madrasas to those in modern schools and colleges in terms of their socio-economic background, attitudinal differences and the level of trust they have on their peers as well as the broader society have also grown (Mwaura et al. 2008; Asadullah et al. 2015; Delavande and Basit 2015). The starting

\footnotetext{
${ }^{1}$ United States, for instance, provided an aid package to General Musharraf's government soon after September 11 for implementation of a madrasa reform program. Due to major distrust of the religious community on the United States as well as on General Musharraf the program failed to enlist most madrasas with the result that the program was closed in 2007 (Bano 2007).
} 
assumption guiding such interventions, and also many media reports, is that madrasa enrolment leads to heightened levels of religiosity (Falak 2013; Ahmad 2015). This assumption, however, is often not properly tested or is at best measured through very simplistic questions about participation in ritual practices. The results presented in this paper question such assertions.

Drawing on survey data on girls in final years of madrasa and modern colleges in urban Pakistan, we show that it is difficult to argue that levels of religiosity between the two groups record statistically significant differences. On most counts of religious behavior the students from the two groups do not show statistically significant differences. In fact, even college girls show very high levels of religiosity, which is understandable in society with high level of religious prevalence. Further, our probit analysis shows that when we control for students' socio-economic profile and attitudes, on few counts of religiosity madrasa effect does emerge but it disappears as soon as we control for parental level of education. Within the broader literature on sociology of education regarding school versus family effect in shaping individual religiosity, the findings of this study thus weigh in favour of the latter.

Traditionally drawing on evidence from Catholic or Jewish schools in the West, academics have been keen to demonstrate the effect of religious schools on students' social attitudes including their levels of religiosity (Tritter 1992; Barrett et al. 2007). Competing evidence instead emphasizes the effect of household religiosity levels both in shaping the preference for religious schools (Sander 2005; CohenZara and Sander 2008) as well as the levels of religiosity (Hill 2011). Religious beliefs are transmitted from parents to children in both direct and indirect ways (Benson et al. 1989). Yet other studies have shown even broader societal factors have an impact on one's religiosity. One of them is the nation itself (Kelley and De Graaf 1997) with its traditions and customs. Such factors tend to remain similar over the years and therefore reinforce people's way of living and thinking. Outside the nuclear family there are many figures that can also exercise influence such as friends (Spilka et al. 2003) and classmates and teachers inside a school environment (Benson et al. 1989). Instead of finding any madrasa effect we find that mother's education has a positive effect on allowing girls to adopt more liberal religious norms.

The structure of the paper is as follows. Section 2 presents the context of Pakistan and the core features of the madrasa and the regular schooling system. Section 3 outlines the survey design. Section 4 presents some basic statistics. Section 5 presents the probit model and discusses the key results. Finally, section 6 concludes. 


\section{BACKGROUND: SECULAR SCHOOLS AND MADRASAS IN PAKISTAN}

Madrasas, Islamic schools, are a centuries old institution of learning in the Islamic world. Traditionally, madrasas were places for training the socio-political elites in Muslim societies covering modern as well as religious subjects (Hefner and Zaman 2007). However, with the establishment of western educational institutions in Muslim countries during the colonial period, madrasas became marginalized and came to focus purely on study of religious subjects. Having lost its socio-economic significance, madrasas in the colonial and post-colonial period failed to attract the socially and economically more affluent classes drawing more and more children from lower income groups. In all Muslim countries, today some kind of madrasa network (formal or informal) aimed at imparting specialized Islamic knowledge runs in parallel to the state schooling system. The graduates of these institutions are trained mainly to take on a position as religious teachers, mosque imams, etc. However, in some countries, such as Pakistan, madrasas have become focus of international attention since September 11 because of an alleged association between madrasas and Islamic militancy.

Such concerns mainly stem from evidence that many of the Taliban leaders had studied in madrasas in Pakistan (Haqqani 2005; Rashid 2010; Ahmad 2015). Actual profiles of militants in Pakistan, however, show that a very small number come from madrasas (Bano 2012). There are also other concerns about madrasa education: focused purely on religious subjects, it is argued to breed sectarianism and intolerance and reinforce a patriarchal value system (Grare 2007; Falak 2013; Ahmad 2015). Such concerns are also expressed about female madrasas, which unlike the male madrasas are normally not associated with militancy ${ }^{2}$. It is assumed that girls in madrasas absorb conservative Islamic norms, which restricts their well-being, such as allowing men to have four wives at any given time when women must secure a divorce before remarrying; women inheriting half the share of men; or need of two female witnesses against one male witness in matters of commerce. Girls in madrasas are argued to imbibe these restrictive religious norms and thereby limit their well-being.

Madrasas in Pakistan thus present a good case to test how participation in a religious versus secular

\footnotetext{
${ }^{2}$ One exception was Jamia Hafsa, a female madrasa in Islamabad that in 2007 supported an armed resistance against General Musharraf's government for the latter's unqualified support of US 'war on terror'.
} 
school effects an individual's level of religiosity. A country of over 180 million, Pakistan shares many features common to developing countries. Despite rapid urbanization an estimated 62 percent of the population still residing in the rural areas. GDP per capita income during 2012-2013 was US\$1,368 (Ministry of Education 2014). State has traditionally prioritized spending on building military defense over investment in human capital. Education sector has thus consistently underperformed due to lack of adequate resources as well as poor governance. While there are many private institutions of excellence from primary to tertiary level, the state education system at the primary and secondary level is severely underperforming. Consequently, the education landscape in Pakistan is highly mixed. The overall literacy rate is only 58 percent and an estimated 6.7 million children remain out of school (Ministry of Education 2014).

The poor education standards in state schools have in turn made many parents even from poor families to send their children to low-fee private schools (Andrabi et al. 2006a). Accordingly to UNESCO Institute for Statistics, close to 35 percent of children in Pakistan ${ }^{3}$ are now going to private schools many of them catering to children from poor families (Andrabi et al. 2006a). Madrasas education is yet another alternative to the poor state schooling system. Starting from primary level, the bigger madrasas run all the way to providing specialized degrees in Islamic subjects, which are equivalent to a master degree in Islamic Studies from a government university. The actual number of madrasa students as share of total population is estimated to be relatively small (Andrabi et al. 2006b). However, their influence in the society through becoming religious teachers and preachers is much greater than reflected in the numbers. Female madrasas primarily offer a four-year specialized Islamic Studies program for girls in the age range of 16-20 years. The secular educational institution equivalent to female madrasas is female colleges, which offer a four-year bachelor degree program to girls of similar age. Girls come to both these institutions after completing their matric (Grade 10) in a high school thus having similar educational background.

The expansion in demand for female madrasas in recent years has been particularly strong. Female madrasa system started operating in Pakistan only in mid to late 1970s whereas the male madrasa network has operated in South Asia since the twelfth century. Yet within forty years, female madrasas have come to constitute 20 per cent of the total madrasa population in Pakistan. Given their growing numbers, it is thus important to assess concerns that madrasa education can restrict female agency

\footnotetext{
${ }^{3}$ Data available online, accessed on 11 December 2016, http://data.worldbank.org/indicator/SE.PRM.PRIV.ZS
} 
by making women endorse restrictive gender norms ${ }^{4}$. This paper thus focuses on comparing the religiosity between students of madrasas and college girls to see if being in a madrasa indeed increases girls' religiosity and their preference for absorbing more conservative religious norms that restrict their own agency.

\section{RESEARCH DESIGN}

The survey was implemented in Lahore and Rawalpindi, two important cities of Punjab, the most populated and politically resourceful province in Pakistan. Lahore is the provincial capital and Rawalpindi is twin city to Pakistan's federal capital, Islamabad. A leading madrasa and a leading college were selected in both the cities. The selected institutions were from among the most prominent institutions representative of their school type in each city. Delavande and Zafar (2015) in their study of trust levels between madrasa and college students in Pakistan use very similar rationale for selecting Lahore and Rawalpindi as the field sites and for focusing on the most prominent institutions of each type to develop their student sample. Students were selected randomly from the two school types using the school register. A total of 282 girls were selected from the two colleges and 195 girls were selected from the two madrasas. In each institution, the survey was implemented by seating all the sampled girls in large hall, normally made available by the participating school. The questions were read out aloud by a research assistant and students were required to mark their response directly on the questionnaire. It took on an average an hour to complete the questionnaire. The questionnaire had six main sections: individual characteristics, family profile and socio-economic background, state of health, locus of control, levels of religiosity, and future aspirations.

Special thought was given when developing questions aimed at measuring religiosity. There is a rich literature, especially within sociology of religion, dedicated to identifying the various components of religious behavior that together arguably help determine individual or collective levels of religiosity. McAndrew and Voas (2011) in a paper titled Measuring Religiosity Using Surveys, argue that religion being highly complex phenomenon is multidimensional in construct. Noting that there is a difference between religious affiliation (nominal association with religion by birth) and religious commitment (attitudes, behavior and values), they argue religiosity to be concerned with the latter. While it is

\footnotetext{
${ }^{4}$ For a discussion on how religious or cultural norms can make women form self-confining preferences see Kabeer (1999).
} 
agreed in the literature that quantification of religiosity is possible, there are no clear standards regarding which of the following aspects, preferred by different studies, should be measured: belief, practice, formal membership, informal affiliation, ritual initiation, doctrinal knowledge, moral sense, core values, or how one regards others. Consequently, studies attempting to measure the impact of school type on levels of religiosity focus on different dimensions of religiosity shaped by what to the authors of those studies is the most convincing measure of religiosity in the given context.

Studies on madrasas have normally simply focused on questions about ritual practice. The questionnaire developed for this survey instead focused on capturing three core dimensions of religiosity: ritual practice, the degree of conviction in fairness of Islamic rulings, and aspirations to be close to God. Such a three dimensional approach was thought to provide more meaningful understanding of one's religiosity than one just focusing on levels of ritual practice. It is widely acknowledged in studies on religiosity that ritual observance is often not the most accurate measure of one's level of religious conviction (Barrett et al. 2007). Participation in ritual practices can be motived by various factors such as a desire to express conformity with expected group norms especially in contexts where lack of observance of the rituals can lead to exclusion from the group. The need to differentiate between responses to publically observable rituals and private religiosity has therefore been emphasized routinely in the studies attempting to measure levels of religiosity (Barrett et al. 2007).

Since madrasas in Pakistan are boarding facilities, it is difficult to treat ritual practice as the best indicator of religiosity as group effect in this case could be expected to have higher impact. Therefore, in this case, the other two dimensions of religiosity were seen to be more important: conviction in the fairness of Islamic norms, and stated aspiration to be close to God. The survey instrument thus developed explicit questions to measure these three dimensions of religiosity. Ritual practice was measured by asking respondents if they performed a specific religious ritual and if yes then how frequently. Ritual practices covered included both obligatory Islamic rituals as well as some optional ones: five compulsory prayers plus the optional tahajjud (midnight prayer); fasting in Ramadan, and levels of giving under the compulsory Islamic obligation of zakat as well as the optional forms of giving sadeeqa and kheerat.

Belief in fairness of Islamic norms was tested by narrating some of the basic Islamic rulings on gender which from a liberal perspective are seen to deny women their basic rights-such as men having the permission to have four wives and women having half the inheritance- and asking the girls, if in their view, by giving men that right, Islam gives women lower status than men. 
Aspiration to be close to God was measured by asking a number of questions within the section on aspirations that could help measure one's desire for religious piety. Key dimensions covered were: aspirations to have time, place, and freedom to pray and pray regularly; to have the time, a place, and freedom to read the Quran and to read the Quran regularly; to have the time, freedom, and the means to do Hajj; to have religious virtue in eyes of those around you; to have religious virtue in her own eyes, and to have religious virtue in the eyes of Allah.

\section{Empirical Evidence}

Table 1 presents chi-square results for the two groups on selected counts of religiosity. As we can see, in almost all the cases, there is not enough evidence to suggest an association between school type and selected dimensions of religiosity. The few exceptions are some of the questions on ritual practice.

Table 1. Levels of Religiosity for Madrasa and College, Pakistan

\section{Madrasa Secular}

$\begin{array}{lllll}\text { Mean } & \text { S.D. Mean } & \text { S.D. } & \mathrm{X}^{2} & \text { p-value }\end{array}$

\section{a) Ritual Practice}

How many times do you pray in the day?

Do you donate Zakat?

Do you donate Sadaqa?

Do you donate Kheerat?

Have you completed the Arabic recitation of the Quran (at least) one time?

\begin{tabular}{cc|cc|cc}
5.240 & 0.460 & 3.547 & 1.482 & 221.502 & 0.000 \\
$50 \%$ & 0.501 & $69.47 \%$ & 0.461 & 16.6577 & 0.000 \\
$97 \%$ & 0.184 & $90 \%$ & 0.298 & 7.0101 & 0.008 \\
$88 \%$ & 0.330 & $90 \%$ & 0.299 & 0.6564 & 0.418 \\
$98.59 \%$ & 0.118 & $96.85 \%$ & 0.174 & 1.5719 & 0.210
\end{tabular}

\section{b) Convictions on Fairness}

Do you think that, by allowing men to marry four wives, Islam gives women lower status than men?

\begin{tabular}{ll|ll|ll}
$10.42 \%$ & 0.308 & $6.92 \%$ & 0.254 & 0.732 & 0.392 \\
$8.02 \%$ & 0.272 & $5.61 \%$ & 0.230 & 1.134 & 0.287 \\
\hline
\end{tabular}

Do you think that, by giving women half the inheritance rights of men, Islam gives women lower status than men?

\section{b) Aspired Levels of Closeness to God}

Do you aspire to have the time, a place, and freedom to pray and to pray regularly?

Do you aspire to have the time, a place, and freedom to read the Quran and to read the Quran regularly?

Do you aspire to have the time, freedom, and the means to do the Hajj?

Do you aspire to have religious virtue in the eyes of those around her?

Do you aspire to have religious virtue in her own eyes?

\begin{tabular}{ll|ll|ll}
$99.02 \%$ & 0.098 & $99.65 \%$ & 0.059 & 0.000 & 0.999 \\
$99.52 \%$ & 0.069 & $96.47 \%$ & 0.184 & 0.0207 & 0.886 \\
$100 \%$ & 0.000 & $98.23 \%$ & 0.132 & 2.923 & 0.087 \\
$98.04 \%$ & 0.138 & $93.17 \%$ & 0.252 & 0.000 & 0.976 \\
$99.02 \%$ & 0.098 & $98.56 \%$ & 0.119 & 0.482 & 0.487 \\
$100 \%$ & 0.000 & $98.22 \%$ & 0.132 & 2.880 & 0.090
\end{tabular}

Do you aspire to have religious virtue in the eyes of Allah?

Source: Own data 
Note: The answer of each question is a dummy whereby 1 and 0 correspond to the answer "yes" or "no" respectively. The only exception is the first question on ritual practice where the response option ranges from 0 to 6 .

\section{THE MODEL AND ROBUSTNESS CHECKS}

The model

Many studies have suggested and empirically proved the presence of parental influence, either direct or indirect, on the religiosity of their offspring (Martin et al. 2003). We show similar results in case of madrasa education and college students through a probit model, similar to one used by Asadullah and Chaudhury (2010), using level of religiosity as a dependent variable.

$Y_{i}^{j}=\mathrm{CM}_{\mathrm{i}} \beta_{1}+\mathrm{P}_{\mathrm{i}} \beta_{2}+\mathrm{Z}_{\mathrm{i}} \beta_{3}+\mathrm{V}_{\mathrm{i}}$

where " $\mathrm{i}$ " is an index identifying each student interviewed whereas " $\mathrm{j}$ " is an index indicating the number of the question related to the level of religiosity which corresponds to the dependent variable $(j=1,2,3,4) . C M$ is a dummy specifying whether a female student is going to a secular school or to a madrasa whereas $\mathrm{P}$ contains personal characteristics and attitude of female students including accommodation, level of education, health condition, number of hours spent per day watching television; $Z$ identifies a list of household characteristics of the respondent ${ }^{5}$.

Since we are interested in assessing the role of parental education on the level of religiosity of female students, we re-write Eqn. (1) in the following form:

\footnotetext{
${ }^{5}$ There are few variables that need further explanation. Female student level of education completed is a categorical variable which range goes from 1 to 4 as follows: 1=middle school completed, 2=Matric/O Level completed; 3=F.A./F.Sc./A Level completed; 4=B.A./B.Sc./B.Com/B.Ed level completed. Rate of health is another categorical variable ranging from 1 to 5 and the values correspond to the following questions: 1 =very good; 2 =good; $3=$ normal; $4=$ poor; $5=$ =very poor. The limit of this variable is the answers come from a subjective point of view of each student because there was no doctor to actually check their health status. Level of internal locus of control is again a categorical variable and the students were expected to give a preference to the following statement: "I believe my chances of success depend on my own abilities". The variable ranges from 1 to 4 where: $1=$ agree strongly; $2=$ agree; $3=$ disagree; $4=$ disagree strongly.
} 
$Y_{i}^{j}=\mathrm{CM}_{\mathrm{i}} \beta_{1}+\mathrm{P}_{\mathrm{i}} \beta_{2}+\mathrm{Z}_{\mathrm{i}} \beta_{3}+\mathrm{E}_{\mathrm{i}} \beta_{4}+\mathrm{V}_{\mathrm{i}}$

The second equation has the same notation and specification of the first one except for the presence of the additional covariate $E$ which is a categorical variable identifying the level of education of the father and mother of each female student ${ }^{6}$. In case of a positive and significant coefficient of the added variable, we can expect the presence of educated parental interaction effect.

Table 2 is a summary of the main characteristics of female students regarding personal attributes, household information, parental economic background and level of education. All given information is filtered according to the school type, either madrasa or secular. Most of the variables are dummies, three of them are categorical and continuous, as explained in note 1.

We can already see some main differences between madrasa and secular female students. The former live in an accommodation provided by the madrasa and have limited or no access to the television while the situation is reverse for college girls. Both groups seem to have, on average, almost the same level of education and rate of health as well as the dummy regarding the presence of any disability. Surprisingly, madrasa students are more likely to have a higher level of internal locus of control though the difference is not so significant.

Table 2. Female students' main characteristics by school type

\begin{tabular}{|c|c|c|c|c|c|c|}
\hline \multirow[t]{2}{*}{ Variable } & \multicolumn{2}{|c|}{ Madrasa } & \multicolumn{2}{|c|}{ Secular } & \multirow[t]{2}{*}{$x^{2}$} & \multirow[t]{2}{*}{ p-values } \\
\hline & Mean & Std. dev. & Mean & Std. dev. & & \\
\hline \multicolumn{7}{|l|}{ Personal characteristics and attitudes } \\
\hline * Live in an accommodation provided by the school & 0.6417 & 0.4808 & 0.1822 & 0.3867 & 98.2652 & 0.000 \\
\hline Female student level of education completed & 2.5744 & 0.8049 & 2.4910 & 0.5358 & 62.2078 & 0.000 \\
\hline \# of hours spent per day watching tv & 1.8413 & 1.4645 & 3.4079 & 1.5822 & 187.6908 & 0.000 \\
\hline *Presence of disability & 0.0052 & 0.0718 & 0.0036 & 0.0601 & 0.0605 & 0.806 \\
\hline Rate of health & 2.3866 & 0.8517 & 2.5632 & 0.9012 & 6.6870 & 0.153 \\
\hline Level of internal locus of control & 1.9365 & 0.8969 & 1.7117 & 0.6354 & 30.6830 & 0.000 \\
\hline${ }^{*}$ Aspire to have a job on your own & 0.8304 & 0.3764 & 0.7926 & 0.4062 & 1.0742 & 0.300 \\
\hline \multicolumn{7}{|l|}{ Parental profile and economic background } \\
\hline *Mother alive & 0.9641 & 0.1865 & 0.9716 & 0.1663 & 0.1954 & 0.658 \\
\hline *Father alive & 0.9333 & 0.2501 & 0.9113 & 0.2847 & 0.8190 & 0.365 \\
\hline $1^{\text {st }}, 2^{\text {nd }}, 3^{\text {rd }} .$. child of your parents & 3.5882 & 2.1039 & 2.8613 & 1.6868 & 33.8993 & 0.000 \\
\hline
\end{tabular}

\footnotetext{
${ }^{6}$ The variable indicating the level of education of the mother and father is a categorical variable and it has the following values: $1=$ none, $2=$ primary, 3=middle, 4= matric/O Level, 5= FA/FSc/A-Levels, 6=BA/BSc/BCom/BEd, $6=\mathrm{MA} / \mathrm{MSc} / \mathrm{MCom} /$ more; $7=$ professional.
} 


\begin{tabular}{lrrrrrr} 
Father income $^{7}$ & 15381.8 & 14434.4 & 51218.1 & 72188.5 & 4.6177 & 0.000 \\
*Father own any land & 0.8316 & 0.3752 & 0.7361 & 0.4416 & 6.1493 & 0.013 \\
*Father read newspaper & 0.5330 & 0.5003 & 0.7658 & 0.4243 & 25.8836 & 0.000 \\
& & & & & & \\
& & & & & & \\
Level of religiosity & & & & & & \\
*Fasting during Ramadan & 0.9897 & 0.1010 & 0.9043 & 0.2948 & 14.9579 & 0.000 \\
*Donating sadaqa & 0.9617 & 0.1923 & 0.9011 & 0.2990 & 5.9400 & 0.015 \\
*Read translated Qur'an & 0.1179 & 0.3234 & 0.3298 & 0.4710 & 26.4715 & 0.000 \\
*Willing to allow your husband marry another wife & 0.5263 & 0.5060 & 0.1667 & 0.3734 & 26.3650 & 0.000 \\
$N$ & 174.5294 & 43.3663 & 269.6471 & 11.1744 & & \\
\hline
\end{tabular}

Source: own survey data.

Most of the data are dummies, i.e. all the variables with an *. The exceptions are: level of education completed, number of hours spent watching TV per day, rate of health, level of locus of control, and father's income. This last one is a continuous variable. The level of education completed has the following values:1=Middle school completed; $2=$ Matric/O Levels; $3=$ F.A./F.Sc./A Levels; 4=B.A./B.Sc./B.Com/B.Ed. The rate of health is rated as: $1=$ very good; $2=$ good; $3=$ normal; $4=$ poor; $5=$ very poor. The level of locus of control is rated according to the answer to the statement "I believe my chances of success depend on my own abilities", which had following response options: 1=agree strongly; 2=agree; $3=$ disagree; 4=disagree strongly.

Interesting differences and similarities are visible in parental profile and economic background of students from the two categories of educational institutions. Girls from both the madrasas as well as secular colleges generally have both parents alive but madrasa girls seem to have more elder siblings and record lower father income comparing to their counter parts in colleges. College girls on the average also have more fathers who read newspaper. When compared to students in colleges, madrasa girls seem to have a little higher level of religiosity as expressed through their responses to questions about fasting during Ramadan, giving sadaqa and having the willingness to allow their husband to marry another wife but a lower one in regard to reading translated Qur'an ${ }^{8}$.

We are mostly interested in analysing the existence of a possible educated parental interaction effect on female students' level of religiosity. Table 3 reports the marginal effects of the probit model for eight sets of regressions where the dependent variable is the level of religiosity measured through four questions on religiosity. The dependent variable is a binary result following the answers that female students gave to the following questions: "Do you fast during Ramadan?"; "Do you regularly donate money under the form of sadaqa?"; "Have you read the Qur'an with translation?" and "Will you be willing to allow your husband to marry another wife?". The answer of the first question is either "occasionally", then the dependent variable takes the value of 0 , or "always" therefore $y$ is equal to 1 . The answer of the second question is either positive, and in that case it takes the value of 1 , or negative therefore the dependent variable is equal to 0 . Regarding the third question, we consider as zero all the answers giving "no" or "some parts" as a response and 1 if the response

\footnotetext{
${ }^{7}$ For the variable "father income", a continuous variable, we calculated the t-test.

${ }^{8}$ We do not consider three cases with a particularly high father's income.
} 
was "the entire Qur'an". Finally, the last question is a simple dummy which takes the value of 1 for a positive answer or zero otherwise.

Regression results reported in table 3 (column 1-2) explores the level of religiosity given by the question about fasting during Ramadan. In our specification, the key determinant is the variable related to madrasa attendance. After controlling for personal attitudes and household socio-economic background, we find that madrasa female students are almost $7 \%$ more likely to fast during Ramadan comparing to their secular school peers. However, as soon as we add two covariates (column 2) related to the level of education of girls' parents, the madrasa effect disappears. The first column refers to equation 1 whereas the second column to equation 2 and so on and so forth for each of the following questions. An interesting result is that the higher is the level of mother education less likely is the probability of a girl to fast during Ramadan. However, the relationship runs in the opposite direction in case of educated father. It seems that a more educated mother allows the daughter greater degree of freedom in choosing which ritual practices to observe. More educated fathers, however, seem to encourage higher degree of religious observance within the household.

Almost the same pattern appears to hold also in the other two cases regarding donating sadaqa and the girls' being willing to allow their husband to have another wife. As soon as we control for the level of parents' education (see column 4 and 8), madrasa attendance loses significance but father education shows a positive relation with a girls' willingness to allow her husband to have another wife. In fact, in the fourth question, students are almost $4 \%$ more likely to allow their husband to have a second wife, the higher the level of father education (column 8) while the opposite result with almost the same magnitude happens in the case of mothers with higher education. The results related to the second question ("Do you regularly donate money in the form of sadaqa?"), do not show any significance relationship to the parental level of education but, at the same time, once we control for parental level of education, madrasa attendance effect again disappears.

These results become even more interesting, when we see the answer to the third question aimed at measuring religiosity on which there is a significant difference in response, 'Have you read the Qur'an with translation?' Since there is a negative sign in front of the estimate it means in case of this question we have a "college effect" 9 " instead of "madrasa effect". Yet, again this school type effect disappears after controlling for parents' level of education. Further, the more educated the father is,

\footnotetext{
${ }^{9}$ With college effect we indicate that a difference in the level of religiosity between the two groups does exist and it is higher for college girls. This case, though, is very rare and it appears only for the question asking about reading the Quran with translation.
} 
almost 7\% more likely is the female students in reading Qur'an with translation. When it comes to interpreting the significance of this question for an individual's level of religiosity, we should keep in mind that all the girls responded positively to reading read the Qur'an in its original language namely Arabic. Thus, those who are trying to read the translated version in addition to the Arabic version are trying to understand its actual meaning more deeply by reading it in their mother tongue.

Summarizing the above results, according to equation 1 , our results do report the existence of madrasa attendance effect or certain important dimensions of one's level of individual religiosity, however, this effect disappears when we control for parental education. There appears to be a distinct and significant correlation between parental education and female students' level of religiosity. It is especially evident through analysis of questions one (Do you fast during Ramadan) and question four (Will you be willing to allow your husband to marry another wife?). Our data shows that higher educated mothers are more supportive of breaking traditional mind set than the fathers. Gender development programs thus need to focus more targeted programmes towards changing the attitudes of the fathers.

Table 3. Marginal effects of the Probit model of determinants of students' characteristics and household profile towards level of religiosity measured with three different variables, with and without control for parental education

\begin{tabular}{|c|c|c|c|c|c|c|c|c|}
\hline & \multicolumn{2}{|c|}{$Y^{1}:$ Fast during Ramadan } & \multicolumn{2}{|c|}{$Y^{2}:$ Donate sadaqa } & \multicolumn{2}{|c|}{$Y^{3}:$ Read translated Qur'an } & \multicolumn{2}{|c|}{$\begin{array}{l}Y^{4}: \text { allow your husband } \\
\text { marry another wife }\end{array}$} \\
\hline & (Eqn. 1) & (Eqn. 2) & (Eqn. 1) & (Eqn. 2) & (Eqn. 1) & (Eqn. 2) & (Eqn. 3) & (Eqn. 4) \\
\hline \multirow[t]{2}{*}{ Attended madrasa } & $0.06788^{*}$ & 0.03313 & $0.07586^{*}$ & 0.06862 & $-0.1753 * *$ & -0.05932 & $0.19219709 *$ & 0.1676443 \\
\hline & $(0.0358)$ & $(0.031)$ & $(0.039)$ & $(0.0427)$ & $(0.0749)$ & $(0.0883)$ & $(0.1021008)$ & $(0.1205261)$ \\
\hline \multirow[t]{2}{*}{ Level of mother education } & & $-0.02051^{* *}$ & & 0.004751 & & 0.001098 & & $-0.03645794 *$ \\
\hline & & $(0.0089)$ & & $(0.0059)$ & & $(0.0211)$ & & $(0.0208869)$ \\
\hline \multirow[t]{2}{*}{ Level of father education } & & $0.01435^{*}$ & & -0.008822 & & $0.05795^{* * *}$ & & $0.03724213^{*}$ \\
\hline & & $(0.0074)$ & & $(0.0071)$ & & $(0.0198)$ & & (0.0203439) \\
\hline \multirow[t]{2}{*}{ Accommodation } & -0.03493 & -0.02441 & $-0.07808^{*}$ & $-0.07057^{*}$ & 0.06800 & 0.05861 & 0.08726381 & 0.07943428 \\
\hline & $(0.0243)$ & $(0.0182)$ & $(0.0404)$ & $(0.0423)$ & $(0.0694)$ & $(0.0665)$ & $(0.0659834)$ & $(0.0670832)$ \\
\hline \multirow[t]{2}{*}{ Level of education completed } & $0.03260^{*}$ & $0.01969 *$ & 0.01019 & 0.01266 & $-0.3304 * * *$ & $-0.3405^{* * *}$ & -0.03729017 & -0.05853187 \\
\hline & $(0.0173)$ & $(0.0118)$ & $(0.0138)$ & $(0.0133)$ & $(0.0479)$ & $(0.0486)$ & $(0.0518732)$ & $(0.0556681)$ \\
\hline \multirow[t]{2}{*}{ \# hrs watching tv } & -0.009761 & -0.008203 & -0.007969 & -0.00774 & 0.005658 & 0.01144 & -0.02043509 & -0.01826115 \\
\hline & $(0.0061)$ & $(0.0051)$ & $(0.0057)$ & $(0.0052)$ & $(0.0203)$ & $(0.0192)$ & $(0.018327)$ & (0.0178229) \\
\hline \multirow[t]{2}{*}{ Disability } & $-0.1798^{* * *}$ & $-0.1620 * * *$ & 0 & 0 & $0.3867 * * *$ & $0.3418^{* * *}$ & 0 & 0 \\
\hline & $(0.0641)$ & $(0.0585)$ & & & $(0.1252)$ & $(0.0955)$ & & \\
\hline \multirow[t]{2}{*}{ Rate of health } & 0.0004464 & 0.0004852 & 0.005746 & 0.004182 & -0.00224 & 0.004693 & -0.0296689 & -0.0248683 \\
\hline & $(0.0129)$ & $(0.0101)$ & $(0.0105)$ & $(0.0091)$ & $(0.0307)$ & $(0.0288)$ & $(0.030461)$ & $(0.030135)$ \\
\hline \multirow[t]{2}{*}{ Internal locus of control } & 0.0138 & 0.01199 & 0.007394 & 0.004645 & 0.01452 & 0.0298 & $0.0780365^{* *}$ & $0.08224136^{* *}$ \\
\hline & $(0.0123)$ & $(0.0093)$ & $(0.0094)$ & $(0.0086)$ & $(0.0318)$ & $(0.0321)$ & 0.0368388 & 0.0822414 \\
\hline \multirow[t]{2}{*}{ Mother alive } & $0.1036^{* *}$ & $0.07612^{* *}$ & 0.06053 & 0.05729 & -0.05077 & -0.05870 & 0.00106649 & -0.01767423 \\
\hline & $(0.0476)$ & $(0.0371)$ & $(0.0528)$ & (0.0529) & $(0.1792)$ & $(0.1721)$ & $(0.147272)$ & $(0.141696)$ \\
\hline Father alive & $0.05870^{*}$ & $0.05483^{* *}$ & -0.01839 & -0.01658 & 0 & 0 & 0.11720882 & 0.11409882 \\
\hline
\end{tabular}




\begin{tabular}{|c|c|c|c|c|c|c|c|c|}
\hline & $(0.0356)$ & $(0.0276)$ & $(0.0388)$ & $(0.0346)$ & & & $(0.1464224)$ & $(0.1408706)$ \\
\hline \multirow[t]{2}{*}{ Number of child among siblings } & 0.001547 & -0.0006874 & 0.004558 & 0.003863 & 0.004615 & 0.01027 & 0.016171 & 0.0153128 \\
\hline & $(0.0058)$ & $(0.004)$ & $(0.0062)$ & $(0.0059)$ & $(0.0141)$ & $(0.0144)$ & $(0.0156854)$ & (0.0158089) \\
\hline \multirow[t]{2}{*}{ Father income } & $1.64 \mathrm{E}-08$ & $1.36 \mathrm{E}-08$ & $2.57 \mathrm{E}-07$ & $2.570 \mathrm{e}-07^{*}$ & $1.666 \mathrm{e}-07^{* *}$ & $1.102 \mathrm{e}-07^{* * *}$ & $3.17 \mathrm{E}-08$ & $3.16 \mathrm{E}-08$ \\
\hline & $(0.0000)$ & $(0.0000)$ & $(0.0000)$ & $(0.0000)$ & $(0.0000)$ & $(0.0000)$ & $(0.0000)$ & $(0.0000)$ \\
\hline \multirow[t]{2}{*}{ Father own any land } & 0.01997 & 0.005527 & -0.02923 & -0.02401 & $-0.1054^{*}$ & $-0.1458^{* *}$ & -0.08939117 & $-0.12113158^{*}$ \\
\hline & $(0.02)$ & $(0.0156)$ & $(0.024)$ & $(0.0231)$ & $(0.059)$ & $(0.0583)$ & $(0.0582576)$ & $(0.0618817)$ \\
\hline $\mathrm{N}$ & 298 & 293 & 283 & 278 & 275 & 271 & 230 & 228 \\
\hline Pseudo $\mathrm{R}^{2}$ & 0.1795 & 0.2528 & 0.1598 & 0.1713 & 0.1985 & 0.2416 & 0.1205 & 0.1383 \\
\hline
\end{tabular}

Note: Standard errors in parentheses. ${ }^{*}$ significant at $10 \% ;{ }^{* *}$ significant at $5 \% ;{ }^{* * *}$ significant at $1 \%$. Only marginal effects are listed.

Source: own survey data.

\section{Robustness checks}

Our results are supported by a set of 16 regressions which represent our robustness checks; they are all summarized in table 4 and 5 . We tried to add one and two variables to check whether the results given by the marginal effects still confirm our findings. Table 4 shows eight regressions which are the same as the ones presented in the benchmark table (table 3) with the only difference that, this time, we added one more variable concerning female students' desire or ambition: a dummy variable asking whether she has any aspiration of having a job on her own (where 1 corresponds to an affirmative answer and zero otherwise). Table 4 reports the results which are identified by the following equations:

$Y_{i}^{j}=\mathrm{CM}_{\mathrm{i}} \beta_{1}+\mathrm{P}_{\mathrm{i}} \beta_{2}+\mathrm{Z}_{\mathrm{i}} \beta_{3}+\mathrm{J}_{\mathrm{i}} \beta_{4}+\mathrm{v}_{\mathrm{i}}$

$Y_{i}^{j}=C M_{i} \beta_{1}+P_{i} \beta_{2}+Z_{i} \beta_{3}+J_{i} \beta_{4}+E_{i} \beta_{5}+V_{i}^{10}$.

Notation and specification of the above equations are the same as Eqn. (1) and (2); the only difference is the addition of the dummy J which identifies the aspiration of having a job on your own.

Table 5 represents another robustness check which differentiates from the previous table because, apart from the aspiration question, we have added another dummy variable: female students were asked whether their father reads newspaper (if positive then the variable assumes the value of 1 ,

${ }^{10}$ In this equation you can notice that $Z$ is the same as the one in Eqn. ( 1 and 2 ) because it includes the same variables listed in table 3 related to family socio-economic background of female students. The same holds for $\mathrm{P}$, as far as personal characteristics and attitudes variables of female students is concerned. 
otherwise 0 ). The set of eight regressions have, therefore, another identification which slightly differs from the previous one as follows:

$Y_{i}^{j}=\mathrm{CM}_{\mathrm{i}} \beta_{1}+\mathrm{P}_{\mathrm{i}} \beta_{2}+\mathrm{Z}_{\mathrm{i}} \beta_{3}+\mathrm{J}_{\mathrm{i}} \beta_{4}+\mathrm{N}_{\mathrm{i}} \beta_{5}+\mathrm{v}_{\mathrm{i}}$

$Y_{i}^{j}=C M_{\mathrm{i}} \beta_{1}+\mathrm{P}_{\mathrm{i}} \beta_{2}+\mathrm{Z}_{\mathrm{i}} \beta_{3}+\mathrm{J}_{\mathrm{i}} \beta_{4}+\mathrm{N}_{\mathrm{i}} \beta_{5}+\mathrm{E}_{\mathrm{i}} \beta_{6}+\mathrm{v}_{\mathrm{i}}$

In this case, another variable $(\mathrm{N})$ is added which reports the dummy related to the question about whether or not the girl's father reads a newspaper on daily basis.

In case of all the dimensions of religiosity analysed in table 4 and 5, madrasa effect disappears again as soon as we control for parental level of education and the level of significance is almost the same as for the ones in table 3; "college effect" persists in question 3. Another interesting point to note is the repeated negative sign in front of mother's level of education; again, it confirms the fact that it is less likely that a higher educated mother has a positive effect on the level of religiosity of her daughter(s). On the other side, father level of education presents constantly a positive sign therefore a female student is $1 \%$ (in the case of fasting during Ramadan) or $4 \%$ (in the case of allowing your husband to marry another wife) more likely to be more religious, in terms of practical actions, the higher the level of education of the father. In sum, the result that madrasa effect disappears once we control for parental level of education persists in all robustness checks.

There are indeed some caveats regarding our methodology. We are not implying causality because we are dealing with data which are mostly self-reported and subjective; therefore, they are not precise and can result in attenuation biases (Bertrand and Mullainathan, 2001). Moreover, it would be interesting to deepen our research to understand the relevance of the "college effect" and to see if it shows a specific pattern as we have shown in case of "madrasa effect". 
Table 4

Rob. Check 1 - more variables: aspire to have a job on your own

\begin{tabular}{|c|c|c|c|c|c|c|c|c|}
\hline & \multicolumn{2}{|c|}{$Y^{1}:$ Fast during Ramadan } & \multicolumn{2}{|c|}{$Y^{2}:$ Donate sadaqa } & \multicolumn{2}{|c|}{$Y^{3}:$ Read translated Qur'an } & \multicolumn{2}{|c|}{$\begin{array}{l}Y^{4}: \text { allow your husband } \\
\text { marry another wife }\end{array}$} \\
\hline & (Eqn. 7) & (Eqn. 8) & (Eqn. 7) & (Eqn. 8) & (Eqn. 7) & (Eqn. 8) & (Eqn. 7) & (Eqn. 8) \\
\hline \multirow[t]{2}{*}{ Attended madrasa } & $0.06598^{* *}$ & 0.03218 & $0.07237^{*}$ & 0.0596 & $-0.1787^{* *}$ & -0.04275 & $0.18678532^{*}$ & 0.1656791 \\
\hline & $(0.0324)$ & $(0.0271)$ & $(0.0388)$ & $(0.0389)$ & $(0.0755)$ & $(0.0910)$ & $(0.1036143)$ & $(0.1222622)$ \\
\hline \multirow[t]{2}{*}{ Level of mother education } & & $-0.01902 * *$ & & 0.003486 & & 0.009532 & & $-0.03582588^{*}$ \\
\hline & & $(0.0086)$ & & $(0.0051)$ & & $(0.0224)$ & & $(0.0210669)$ \\
\hline \multirow[t]{2}{*}{ Level of father education } & & $0.01335^{*}$ & & -0.007976 & & $0.05572^{* * *}$ & & $0.03686701^{*}$ \\
\hline & & $(0.0069)$ & & $(0.0067)$ & & $(0.0204)$ & & $(0.0204058)$ \\
\hline \multirow[t]{2}{*}{ Accommodation } & -0.03328 & -0.02311 & $-0.07332^{*}$ & -0.06261 & 0.08826 & 0.08033 & 0.0893512 & 0.08241678 \\
\hline & $(0.0228)$ & $(0.0161)$ & $(0.0383)$ & $(0.0388)$ & $(0.0706)$ & (0.0679) & $(0.0671944)$ & $(0.068422)$ \\
\hline \multirow[t]{2}{*}{ Level of education completed } & $0.03253^{*}$ & 0.0187 & 0.0103 & 0.01163 & $-0.3517^{* * *}$ & $-0.3591 * * *$ & -0.03862511 & -0.06000657 \\
\hline & $(0.0169)$ & $(0.0114)$ & $(0.0132)$ & $(0.012)$ & $(0.0497)$ & $(0.0507)$ & $(0.0536405)$ & $(0.0573993)$ \\
\hline \multirow[t]{2}{*}{ \# hrs watching tv } & -0.009377 & -0.007531 & -0.007129 & -0.006455 & 0.004517 & 0.00922 & -0.02039539 & -0.01841583 \\
\hline & $(0.0061)$ & $(0.0047)$ & $(0.0051)$ & $(0.0045)$ & $(0.0206)$ & $(0.0195)$ & $(0.0184147)$ & $(0.0179627)$ \\
\hline \multirow[t]{2}{*}{ Disability } & $-0.1630 * * *$ & $-0.1427^{* * *}$ & 0 & 0 & $0.3673^{* * *}$ & $0.3303^{* * *}$ & 0 & 0 \\
\hline & $(0.0601)$ & $(0.0539)$ & & & $(0.1278)$ & (0.0995) & & \\
\hline \multirow[t]{2}{*}{ Rate of health } & 0.002821 & 0.002762 & 0.00658 & 0.004914 & 0.002745 & 0.001282 & $-3.15 E-02$ & -0.02610396 \\
\hline & $(0.0123)$ & $(0.0091)$ & $(0.0097)$ & $(0.0081)$ & $(0.0316)$ & $(0.03)$ & $(0.0309076)$ & $(0.0305859)$ \\
\hline \multirow[t]{2}{*}{ Internal locus of control } & 0.0145 & 0.01215 & 0.006652 & 0.004328 & 0.03361 & 0.04887 & $0.07640815^{* *}$ & $.08090621^{* *}$ \\
\hline & $(0.0119)$ & $(0.0088)$ & $(0.0093)$ & $(0.0083)$ & $(0.0350)$ & $(0.0360)$ & $(0.0374742)$ & $(0.038163)$ \\
\hline \multirow[t]{2}{*}{ Mother alive } & $0.08893^{*}$ & $0.06348^{*}$ & 0.04915 & 0.04405 & -0.02077 & -0.03339 & 0.00525432 & -0.01467305 \\
\hline & $(0.0457)$ & $(0.0338)$ & $(0.0477)$ & $(0.0453)$ & $(0.1806)$ & $(0.1727)$ & $(0.1501963)$ & $(0.1444158)$ \\
\hline \multirow[t]{2}{*}{ Father alive } & $0.06196^{*}$ & $0.04951^{*}$ & -0.01618 & -0.01327 & 0 & 0 & 0.11772674 & 0.11588386 \\
\hline & $(0.0347)$ & $(0.0267)$ & $(0.0383)$ & $(0.0321)$ & & & $(0.1492083)$ & $(0.1433969)$ \\
\hline \multirow[t]{2}{*}{ Number of child among siblings } & 0.001551 & -0.0006655 & 0.004994 & 0.00407 & 0.00433 & 0.01009 & 0.01625444 & 0.01545659 \\
\hline & $(0.0053)$ & $(0.0035)$ & $(0.0059)$ & $(0.0053)$ & $(0.015)$ & $(0.0154)$ & $(0.0157933)$ & $(0.0160056)$ \\
\hline \multirow[t]{2}{*}{ Father income } & $1.79 \mathrm{E}-08$ & $1.42 \mathrm{E}-08$ & $2.54 \mathrm{E}-07$ & $2.561 \mathrm{e}-07^{* *}$ & $1.565 \mathrm{e}-07^{* *}$ & $1.006 \mathrm{e}-07^{* * *}$ & $3.03 \mathrm{E}-08$ & $3.06 \mathrm{E}-08$ \\
\hline & $(0.000)$ & $(0.000)$ & $(0.000)$ & $(0.000)$ & $(0.000)$ & $(0.000)$ & $(0.0000)$ & $(0.0000)$ \\
\hline \multirow[t]{2}{*}{ Father own any land } & 0.02458 & 0.008094 & -0.02683 & -0.02182 & $-0.1004^{*}$ & $-0.1334 * *$ & -0.08991403 & $-.12051399 *$ \\
\hline & $(0.019)$ & $(0.0137)$ & $(0.023)$ & (0.0209) & $(0.0615)$ & $(0.0602)$ & $(0.0591349)$ & $(0.0627758)$ \\
\hline \multirow[t]{2}{*}{ Aspire to have a job on your own } & $-0.06066^{*}$ & $-0.04238^{*}$ & -0.04623 & -0.04086 & 0.1044 & 0.09506 & 0.02426119 & 0.01074062 \\
\hline & $(0.036)$ & $(0.0255)$ & $(0.0376)$ & $(0.0359)$ & $(0.0769)$ & $(0.0732)$ & $(0.0718821)$ & $(0.0717136)$ \\
\hline \multicolumn{9}{|l|}{ Father read newspaper } \\
\hline$N$ & 289 & 285 & 274 & 270 & 266 & 263 & 227 & 225 \\
\hline Pseudo $\mathrm{R}^{2}$ & 0.2026 & 0.2773 & 0.1828 & 0.1961 & 0.2120 & 0.2567 & 0.1197 & 0.1363 \\
\hline
\end{tabular}

Note: Standard errors in parentheses. ${ }^{*}$ significant at $10 \%{ }^{* *}$ significant at $5 \% ;{ }^{* * *}$ significant at $1 \%$. Only marginal effects are listed.

Source: own survey data. 
Table 5

Rob. Check 2 - more variables: aspire own job and father read news

\begin{tabular}{|c|c|c|c|c|c|c|c|c|}
\hline & \multicolumn{2}{|c|}{$Y^{1}:$ Fast during Ramadan } & \multicolumn{2}{|c|}{$Y^{2}:$ Donate sadaqa } & \multicolumn{2}{|c|}{$Y^{3}:$ Read translated Qur'an } & \multicolumn{2}{|c|}{$\begin{array}{l}Y^{4}: \text { allow your husband } \\
\text { marry another wife }\end{array}$} \\
\hline & (Eqn. 9) & (Eqn. 10) & (Eqn. 9) & (Eqn. 10) & (Eqn. 9) & (Eqn. 10) & (Eqn. 9) & (Eqn. 10) \\
\hline \multirow[t]{2}{*}{ Attended madrasa } & $0.07475701^{* *}$ & 0.03259 & $0.06846^{*}$ & 0.05927 & $-0.1518^{* *}$ & -0.04517 & $0.1855134^{*}$ & 0.16466075 \\
\hline & $(0.030771)$ & $(0.0245)$ & $(0.0387)$ & $(0.0388)$ & $(0.0756)$ & $(0.0934)$ & $(0.1061749)$ & $(0.1231584)$ \\
\hline \multirow[t]{2}{*}{ Level of mother education } & & $-0.01751^{* *}$ & & 0.003469 & & 0.01166 & & $-0.03532602^{*}$ \\
\hline & & $(0.0083)$ & & $(0.0051)$ & & $(0.0227)$ & & $(0.0212284)$ \\
\hline \multirow[t]{2}{*}{ Level of father education } & & 0.009282 & & -0.007891 & & $0.04693^{* *}$ & & $0.03809344^{*}$ \\
\hline & & $(0.0058)$ & & $(0.0072)$ & & $(0.0212)$ & & $(0.0210049)$ \\
\hline \multirow[t]{2}{*}{ Accommodation } & -0.03325 & -0.01959 & $-0.07115^{*}$ & -0.06195 & 0.1016 & 0.09435 & 0.09323516 & 0.08493553 \\
\hline & $(0.0211)$ & $(0.0152)$ & $(0.04)$ & $(0.0392)$ & $(0.0711)$ & $(0.0688)$ & $(0.0678264)$ & $(0.0693031)$ \\
\hline \multirow[t]{2}{*}{ Level of education completed } & 0.02198 & 0.01065 & 0.01054 & 0.01117 & $-0.3766 * * *$ & $-0.3693 * * *$ & -0.04061831 & -0.05879091 \\
\hline & $(0.015)$ & $(0.01)$ & $(0.0127)$ & $(0.0117)$ & $(0.0512)$ & $(0.0512)$ & $(0.0555704)$ & $(0.0584352)$ \\
\hline \multirow[t]{2}{*}{ \# hrs watching tv } & -0.008591 & -0.006075 & -0.007042 & -0.006456 & -0.0003829 & 0.006121 & -0.02114354 & -0.01855605 \\
\hline & $(0.0058)$ & $(0.0044)$ & $(0.005)$ & $(0.0045)$ & $(0.0208)$ & $(0.0201)$ & $(0.0185212)$ & $(0.0179548)$ \\
\hline \multirow[t]{2}{*}{ Disability } & $-0.1428 * *$ & $-0.1185^{* *}$ & 0 & 0 & $0.3979 * * *$ & $0.3529 * * *$ & 0 & 0 \\
\hline & $(0.0603)$ & $(0.0506)$ & & & $(0.1115)$ & $(0.0988)$ & & \\
\hline \multirow[t]{2}{*}{ Rate of health } & 0.006672 & 0.006166 & 0.006583 & 0.005231 & -0.001817 & -0.0001949 & -0.0334972 & -0.02827461 \\
\hline & $(0.0111)$ & $(0.0076)$ & $(0.0096)$ & $(0.0083)$ & $(0.0316)$ & $(0.0302)$ & $(0.0314036)$ & $(0.0312262)$ \\
\hline \multirow[t]{2}{*}{ Internal locus of control } & 0.01546 & 0.01049 & 0.00665 & 0.004621 & 0.02428 & 0.04 & $0.0741302 *$ & $0.07926948^{* *}$ \\
\hline & $(0.0111)$ & $(0.0074)$ & $(0.0093)$ & $(0.0083)$ & $(0.0357)$ & $(0.0372)$ & $(0.0379341)$ & $(0.0389851)$ \\
\hline \multirow[t]{2}{*}{ Mother alive } & $0.08365^{*}$ & $0.05587^{*}$ & 0.04798 & 0.04379 & -0.04742 & -0.04509 & 0.00525502 & -0.00996781 \\
\hline & $(0.0434)$ & $(0.0318)$ & $(0.0477)$ & $(0.0455)$ & $(0.172)$ & $(0.1701)$ & $(0.1513633)$ & $(0.1456899)$ \\
\hline \multirow[t]{2}{*}{ Father alive } & 0.05215 & $0.04228^{*}$ & -0.01527 & -0.01308 & 0 & 0 & 0.11716155 & 0.1211732 \\
\hline & $(0.0328)$ & $(0.0251)$ & $(0.0368)$ & $(0.0319)$ & & & $(0.1477117)$ & $(0.1426351)$ \\
\hline \multirow[t]{2}{*}{ Number of child among siblings } & 0.0002704 & -0.001793 & 0.004833 & 0.003935 & 0.002763 & 0.008533 & 0.01584186 & 0.01583168 \\
\hline & $(0.0047)$ & $(0.003)$ & $(0.0057)$ & $(0.0052)$ & $(0.0153)$ & $(0.0156)$ & $(0.0160404)$ & $(0.0165396)$ \\
\hline \multirow[t]{2}{*}{ Father income } & $9.30 \mathrm{E}-09$ & $9.67 \mathrm{E}-09$ & $2.650 \mathrm{e}-07^{*}$ & $2.569 \mathrm{e}-07^{* *}$ & $1.240 \mathrm{e}-07^{* * *}$ & $9.335 \mathrm{e}-08^{* * *}$ & $2.87 \mathrm{E}-08$ & $3.04 \mathrm{E}-08$ \\
\hline & '(0.000) & '(0.000) & '(0.000) & '(0.000) & '(0.000) & '(0.000) & $(0.0000)$ & $(0.0000)$ \\
\hline \multirow[t]{2}{*}{ Father own any land } & 0.02514 & 0.009191 & -0.02579 & -0.02176 & $-0.1018^{*}$ & $-0.1270^{* *}$ & -0.08938376 & $-0.12018487^{*}$ \\
\hline & $(0.018)$ & (0.0119) & $(0.0223)$ & $(0.0207)$ & $(0.0612)$ & $(0.0608)$ & $(0.0595661)$ & $(0.0631445)$ \\
\hline \multirow[t]{2}{*}{ Aspire to have a job on your own } & $-0.06004^{*}$ & $-0.03827^{*}$ & -0.04425 & -0.04071 & 0.1042 & 0.09546 & 0.02652424 & 0.0133376 \\
\hline & $(0.0343)$ & $(0.0225)$ & $(0.0386)$ & $(0.0367)$ & $(0.0758)$ & $(0.0739)$ & $(0.0722914)$ & $(0.0724213)$ \\
\hline \multirow[t]{2}{*}{ Father read newspaper } & $0.03805^{*}$ & $0.02855^{*}$ & -0.006507 & -0.0004268 & $0.1606^{* * *}$ & 0.07698 & 0.00876899 & -0.01615292 \\
\hline & $(0.0212)$ & $(0.017)$ & (0.0159) & $(0.016)$ & $(0.0608)$ & $(0.0636)$ & $(0.0609324)$ & $(0.0656371)$ \\
\hline$N$ & 286 & 282 & 273 & 269 & 263 & 260 & 225 & 223 \\
\hline Pseudo $\mathrm{R}^{2}$ & 0.231 & 0.3089 & 0.1842 & 0.1968 & 0.2337 & 0.2611 & 0.1196 & 0.1355 \\
\hline
\end{tabular}

Note: Standard errors in parentheses. ${ }^{*}$ significant at $10 \% ;{ }^{* *}$ significant at $5 \% ;{ }^{* * *}$ significant at $1 \%$. Only marginal effects are listed.

Source: own survey data 


\section{CONCLUSION}

Since September 11, madrasas have been under constant scrutiny of international security establishment and also of many development agencies for their alleged role in promoting heightened levels of religiosity. In case of madrasas catering to male students, these concerns have also linked to recruitment for jihad. Our results suggest that assumptions about madrasa attendance effect on student's level of religiosity in Pakistan are exaggerated. Apart from the fact that we found no significant difference between the levels of religiosity of madrasa girls as compared to those in modern colleges, our analysis shows that any differences in religious outlook are influenced not by religious school attendance but by a number of socio-economic differences in the profile of the two groups, most noticeably the difference in the level of education of their parents. Most importantly, our results demonstrate a strong effect of mother's education on a student's ability to exercise more progressive choices and exercise greater freedom to choose whether or not to undertake religious rituals or conform to conservative religious norms that can be confining of her agency, such as allowing a husband to have a second wife. Involving mothers in gender empowerment programs aimed at young girls is thus likely to prove an effective strategy. At the same time, the links that we have found between higher levels of fathers' education and increased religiosity in girls highlights the need to design interventions targeted directly at male family members to make them active agents in gender empowerment programs. 


\section{REFERENCES}

Ahmad, M., 2015. Madrassas and militancy, 15 February 2015, accessed on 15 July 2017.

https://tribune.com.pk/story/838890/madrassas-and-militancy-2/.

Andrabi, T., Das, J., and Khwaja, A.I., 2006a. A dime a day: The possibilities and limits of private schooling in Pakistan. World Bank Policy Research Working Paper No. 4066.

Andrabi, T., Das, J., Khwaja, A. I., \& Zajonc, T., 2006b. Religious school enrollment in Pakistan: A look at the Data. Comparative Education Review. 50(3), 446-477.

Asadullah, M. N., Chakrabarti, R., \& Chaudhury, N., 2015. What determines religious school choice? Theory and evidence from rural Bangladesh. Bulletin of Economic Research. 67(2), 186-207.

Asadullah, M. N., \& Chaudhury, N., 2010. Religious schools, social values, and economic attitudes: evidence from Bangladesh. World Development. 38(2), 205-217.

Bano, M., 2007. Contesting ideologies and struggle for authority: State-madrasa engagement in Pakistan. Religions and Development Research Programme Working Paper 14, University of Birmingham.

Bano, M., 2012. The rational believer: Choices and decisions in the madrasas of Pakistan. Ithaca: Cornell University Press.

Barrett, J.B., Pearson, J., Muller, C., and Frank, K.A., 2007. Adolescent religiosity and school contexts. Social Science Quarterly, 88(4).

Benson, P. L., Donahue, M. J., \& Erickson, J. A., 1989. Adolescence and religion: A review of the literature from 1970 to 1986. Research in the Social Scientific Study of Religion. 1(1), 153-81.

Bertrand, M., \& Mullainathan, S., 2001. Do people mean what they say? Implications for subjective survey data. The American Economic Review. 91(2), 67-72.

Cohen-Zada, D. and Sander, W. 2007. Religion, religiosity and private school choice: Implications for estimating the effectiveness of private schools. Journal of Urban Economics. 64, 85-100.

Dee, T. S., 2004. Are there civic returns to education? Journal of Public Economics, 88(9), 1697-1720. Delavande, A. and Zafar Basit., 2015. Stereotypes and madrasas: Experimental evidence from Pakistan. Journal of Economic Behavior and Organisation. 118, 247-267.

Falak, A., 2013. How madrassas fuel sectarianism, 29 November 2013, accessed on 14 July 2017, http://nation.com.pk/columns/29-Nov-2013/how-madrassas-fuel-sectarianism.

Grare, F., 2007. The evolution of sectarian conflicts in Pakistan and the ever-changing face of Islamic violence. Journal of South Asian Studies. 30(1), 127-143.

Haqqani, H., 2005. Pakistan: Between mosque and military. Lahore: Vanguard.

Hefner, R. W., \& Zaman, M. Q., 2007. Schooling Islam: The culture and politics of modern Muslim education. Princeton: Princeton University Press. 
Helliwell, J. F., \& Putnam, R. D., 1999. Education and social capital. National Bureau of Economic Research. Working paper No. 7121.

Hill, J. P., 2011. Faith and understanding: Specifying the impact of higher education on religious belief. Journal for the Scientific Study of Religion. 50(3), 533-551.

Kabeer, N., 1999. Resources, agency, achievements: Reflections on measurement of women's empowerment. Development and Change. 30, 435-464.

Kelley, J., \& De Graaf, N. D., 1997. National context, parental socialization, and religious belief: Results from 15 nations. American Sociological Review, 639-659.

Martin, T. F., White, J. M., \& Perlman, D., 2003. Religious socialization: A test of the channeling hypothesis of parental influence on adolescent faith maturity. Journal of Adolescent Research, 18(2), 169-187.

McAndrew, S. and Voas, D., 2011. Measuring religiosity using surveys. https://www.ukdataservice.ac.uk/media/263004/discover_sqb_religion_mcandrew_voas.pdf Milligan, K., Moretti, E., \& Oreopoulos, P., 2004. Does education improve citizenship? Evidence from the United States and the United Kingdom. Journal of public Economics, 88(9), 1667-1695.

Mwaura, P. A., Sylva, K., \& Malmberg, L. E., 2008. Evaluating the Madrasa preschool programme in East Africa: a quasi-experimental study. International Journal of Early Years Education. 16(3), 237-255. Ministry of Education, 2014. Pakistan: Education for All 2015 National Review. Islamabad: Government of Pakistan. Available online, accessed 11 December 2016, http://unesdoc.unesco.org/images/0022/002297/229718E.pdf.

Rashid, Ahmed, 2010. Taliban: Militant Islam, oil and fundamentalism in Central Asia. New Haven, CT: Yale University Press.

Spilka, B., Hood, R. W., Hunsberger, B., \& Gorsuch, R., 2003. The psychology of religion: An empirical approach. New York: Guilford Press.

Tritter, J., 1992. An educated change in moral values: some effects of religious and state schools on their students. Oxford Review of Education, 18 (1), 29-43. 